\title{
Lignocaine Therapy for Ventricular Ectopic Activity after Acute Myocardial Infarction: A Double-blind Trial*
}

\author{
M. P. CHOPRA, U. THADANI, R. W. PORTAL, CLIVE P. ABER
}

British Medical fournal, 1971, 3, 668-670

\section{Summary}

The effectiveness of intravenous lignocaine in suppressing ventricular ectopic activity after acute myocardial infarction was examined in a double-blind trial in 82 patients. Whereas suppression of unifocal ventricular ectopics was achieved by lignocaine in $90 \%$ of patients, other forms of potentially more dangerous ectopic activity (multifocal or R-on-T ectopics) seemed more resistant to therapy. Cessation of ectopic activity was also observed in about one-third of the patients in the control group. The incidence of ventricular tachycardia and fibrillation and the mortality during and after the trial period were similar in the lignocaine-treated and control groups, whether or not the initial ventricular ectopics had been suppressed.

This study provides no evidence to support the routine use of intravenous lignocaine in the management of ventricular ectopic activity after acute myocardial infarction.

\section{Introduction}

Intravenous lignocaine is of proved effectiveness in suppressing ventricular ectopic activity after acute myocardial infarction and is probably now the drug most widely used for this purpose (Gianelly et al., 1967; Lown et al., 1967; Jewitt et al., 1968; Spracklen et al., 1968; Chopra et al., 1969; Mogensen, 1970). Its routine prophylactic administration has recently been recommended for all patients with suspected or proved myocardial infarction (Pitt et al., 1971), yet its value in reducing the incidence of dangerous ventricular arrhythmias or the final hospital mortality remains uncertain (Bennett et al., 1970).

The present double-blind trial was therefore designed to re-examine the effectiveness of intravenous lignocaine in suppressing ventricular ectopic activity after acute myocardial infarction and, in particular, to see whether the overall incidence of major ventricular arrhythmias and hospital mortality were influenced by this form of therapy.

\section{Patients and Methods}

\section{SELECTION OF PATIENTS}

Eighty-two patients ( 63 men and 19 women) aged 33 to 72 years were included in the study. They were selected from 805 patients with acute myocardial infarction admitted to the coronary care unit, Kingston General Hospital, Hull, between

*This study formed the basis of a thesis by M. P. C. for the degree of M.PHIL. at the University of Leeds.

Department of Cardiology, Kingston General Hospital, Hull HU3 1UR M. P. CHOPRA, M.B., M.PHIL., Research Assistant (Recipient of Research Grant from Leeds Regional Hospital Board)

U. THADANI, M.B., M.R.C.P., Registrar (Present address: Cardiovascular Unit, Leeds General Infirmary)

September 1968 and March 1971. The diagnosis of infarction was based on conventional E.C.G. and serum enzyme criteria.

All 82 patients showed one or more of the following types of ventricular ectopic activity within 72 hours of infarction: (1) unifocal ectopics at a rate of more than five per minute; (2) two or more, but less than five, consecutive ectopics; (3) multifocal ectopics; and (4) ectopics occurring during the "vulnerable period" of the preceding beat-that is, a $\mathrm{QR}^{\prime} / \mathrm{QT}$ ratio of less than 0.85 , where $Q R$ ' is the interval between the onset of the normal QRS complex preceding the ectopic and the $R$ wave of the ectupic beat, and QT is the duration of the normal QRST complex.

Patients were excluded from the trial if they had developed circulatory shock, cardiac failure, cardiac arrest, or any other arrhythmias.

\section{PROGRAMME OF INTRAVENOUS THERAPY}

Patients who fulfilled the criteria for inclusion in the trial were allocated to a lignocaine or control (normal saline) group according to a randomized numerical code, the key to which was disclosed only at the end of the trial. At the first observation of ventricular ectopic activity the patient received a course of "treatment" as follows:

(1) A single rapid intravenous injection of the contents of a numbered $1-\mathrm{ml}$ ampoule containing either $50 \mathrm{mg}$ of lignocaine or $1 \mathrm{ml}$ of normal saline (first bolus).

(2) If the ectopic activity was still present five minutes after the injection the contents of a numbered 2-ml ampoule containing either $100 \mathrm{mg}$ of lignocaine or $2 \mathrm{ml}$ of normal saline were injected (second bolus).

(3) If the ectopic activity was suppressed by either the first or second bolus a continuous intravenous infusion, using the contents of a $20-\mathrm{ml}$ ampoule added to $480 \mathrm{ml}$ of $5 \%$ dextrose solution, was administered at a rate of $0.5 \mathrm{ml} /$ minute (8 drops). This ampoule contained either $1,000 \mathrm{mg}$ of lignocaine or $20 \mathrm{ml}$ of normal saline. The infusion thus delivered lignocaine at a rate of $1 \mathrm{mg} /$ minute.

(4) If the ectopic activity recurred after starting the infusion the drip rate was increased to $1 \mathrm{ml} /$ minute, thus delivering lignocaine at a rate of $2 \mathrm{mg} / \mathrm{minute}$.

(5) The infusion was continued for 24 hours and then tapered off by a reduction of the infusion rate to half the previous rate for two hours.

(6) In patients whose ectopic activity was not suppressed by either the first or the second bolus no further treatment was given.

At the conclusion of the trial random samples of the lignocaine solutions were analyzed. Their concentration was unchanged and there had been no contamination.

\section{OBSERVATIONS AND MANAGEMENT}

On admission each patient was given a Peel prognostic score (Peel et al., 1962). While in the coronary care unit continuous oscilloscope monitoring was maintained. Conventional 12-lead E.C.G.s were recorded daily for at least three days and then weekly, or more often if indicated. Throughout the trial period continuous E.C.G. recordings were obtained during the intravenous (bolus) injections and for one minute afterwards. Ten-second strips were then recorded at minute intervals for five minutes. During the continuous intravenous infusion a 10-second tracing was recorded every 15 minutes during the first hour and then hourly throughout the remainder of the trial period. 
Serial determinations of serum aspartate aminotransferase and serum hydroxybutyrate dehydrogenase were made in 79 patients on the first three days for diagnostic purposes and in an attempt to evaluate the extent of the myocardial necrosis (Rosalki, 1963; Nachlas et al., 1964).

Arterial $\mathrm{pH}$ and blood gas tensions were measured in 60 patients at the onset of ventricular ectopic activity with a direct-reading ultra-micro $\mathrm{pH} / \mathrm{gas}$ system (Instrumentation Laboratory Model 113-S1). In 23 patients these measurements were repeated after suppression of the ectopics by the first or second bolus. All patients received humidified oxygen through a Franklin nasal catheter at a rate of $\mathbf{4}$ litres/minute for $\mathbf{4 8}$ hours.

Anticoagulant therapy (intravenous heparin and warfarin) was given to 44 of the 82 patients. Patients over 65 and those with a history of dyspepsia, hypertension, or a bleeding disorder did not receive anticoagulants. Nineteen of the 44 patients were receiving heparin at the time of entering the trial.

\section{Results}

The randomization resulted in two clinically well-matched groups-39 patients in the lignocaine group and 43 in the control group.* The incidence of the different types of ventricular ectopics in the two groups is shown in Table I. The mean interval between acute myocardial infarction and entering the trial was $14 \cdot 2$ hours in the lignocaine group and 12.4 hours in the control group $(P>0.5)$.

Initial Suppression of Ectopics. - The response to the intravenous boluses is shown in Table II. The effect of the first injection ( $50 \mathrm{mg}$ of lignocaine or $1 \mathrm{ml}$ of saline) was not significantly different in the two groups $(P \simeq 0 \cdot 3)$. A highly significant suppressive effect was observed after the second bolus $(100 \mathrm{mg}$ of lignocaine) in the lignocaine group $(P<0.00012)$. The ventricular ectopics were unaffected by either bolus in 10 patients $(26 \%)$ in the lignocaine group and 29 patients $(67 \%)$

* Data available on request to M.P.C.

TABLE I-Incidence of Various Types of Ventricular Ectopic Activity in 82 Patients after Acute Myocardial Infarction

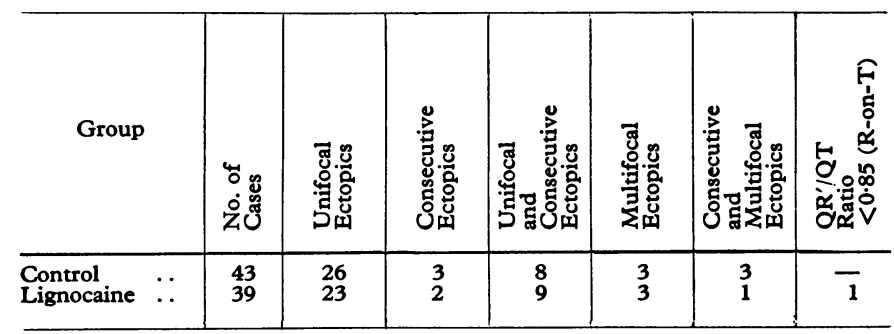

TABLE II-Response of Ventricular Ectopic Activity to Intravenous Boluses in 82 Patients after Acute Myocardial Infarction

\begin{tabular}{|c|c|c|c|c|}
\hline \multirow{2}{*}{ Group } & \multicolumn{3}{|c|}{ Suppression } & \multirow{2}{*}{ No Suppression } \\
\hline & Bolus 1 & Bolus 2 & Total & \\
\hline $\begin{array}{l}\text { Control } \\
\text { Lignocaine } . .\end{array}$ & $\begin{array}{l}12 \\
16\end{array}$ & $\begin{array}{r}2 \\
13\end{array}$ & $\begin{array}{l}14 \\
29\end{array}$ & $\begin{array}{l}29 \\
10\end{array}$ \\
\hline
\end{tabular}

TABLE III-Relationship between Response to Intravenous Lignocaine Boluses and Type of Ventricular Ectopic Activity

\begin{tabular}{|c|c|c|c|c|c|c|}
\hline & 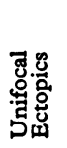 & 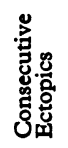 & 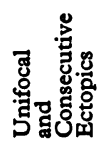 & 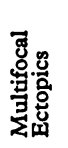 & 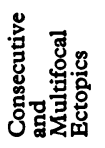 & 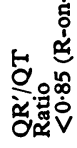 \\
\hline $\begin{array}{l}\text { Total patients } \\
\text { Suppression } \\
\text { No suppression }\end{array}$ & $\begin{array}{r}23 \\
21 \\
2\end{array}$ & $\begin{array}{r}2 \\
2 \\
-\end{array}$ & $\begin{array}{l}9 \\
6 \\
3\end{array}$ & $\frac{3}{3}$ & $\frac{1}{1}$ & $\frac{1}{1}$ \\
\hline
\end{tabular}

in the control group. The effect of the lignocaine boluses on the different types of ectopic activity is shown in Table III. The response to lignocaine was unrelated to the weight of the patient, the severity of the clinical picture (the Peel Index), the site of infarction, the maximal serum enzyme level, the use of heparin, or the initial arterial $\mathrm{pH}$ or blood gas tensions. Furthermore, no significant change in these latter values was observed after the administration of lignocaine or normal saline boluses, whether or not suppression was achieved.

Maintained Suppression.-A continuous intravenous infusion was maintained for 24 hours in 43 patients-29 in the lignocaine group and 14 in the control group. The response is shown in Table IV. Suppression was maintained in $90 \%$ of patients in the lignocaine group and $72 \%$ in the control group. In 14 patients in the lignocaine group and two in the control group an increase in the rate of infusion (from 0.5 to $1 \mathrm{ml} / \mathrm{min}$ ) had to be made in order to maintain suppression.

TABLE IV-Response of Ventricular Ectopic Activity to Continuous Intravenous Infusion in 43 Patients with Acute Myocardial Infarction

\begin{tabular}{|c|c|c|c|c|c|}
\hline \multirow{2}{*}{\multicolumn{2}{|c|}{ Group }} & \multicolumn{3}{|c|}{ Suppression } & \multirow{2}{*}{ No Suppression } \\
\hline & & $1 \mathrm{mg} / \mathrm{min}$ & $2 \mathrm{mg} / \mathrm{min}$ & Total & \\
\hline $\begin{array}{l}\text { Control } \\
\text { Lignocaine }\end{array}$ & $\because$ & $\begin{array}{r}8 \\
12\end{array}$ & $\begin{array}{r}2 \\
14\end{array}$ & $\begin{array}{l}10 \\
26\end{array}$ & $\begin{array}{l}4 \\
3\end{array}$ \\
\hline
\end{tabular}

\section{INCIDENCE OF MAJOR VENTRICULAR ARRHYTHMIAS}

Ventricular Tachycardia.-During the trial period 3 of the 39 patients $(8 \%)$ in the lignocaine group and 4 of the $43(9 \%)$ in the control group showed transient ventricular tachycardia within 7 to 46 hours of infarction. The incidence of ventricular tachycardia was similar $(P \simeq 0.25)$ in the group of patients (36) whose ectopic activity was suppressed during the trial period and in those (46) in whom it was not suppressed (Table V). Two patients developed ventricular tachycardia after the trial period on the fifth and seventh days after infarction. In these patients the arrhythmia was heralded by recurrent ventricular ectopics with a $\mathrm{QR}^{\prime} / \mathrm{QT}$ ratio of 0.88 and 0.99 respectively and both later developed ventricular fibrillation.

TABLE v-Incidence of Major Ventricular Arrhythmias in the 82 Trial Patients

\begin{tabular}{|c|c|c|c|c|c|}
\hline & & \multicolumn{2}{|c|}{$\begin{array}{c}\text { Suppression Group } \\
\text { (36 Patients) }\end{array}$} & \multicolumn{2}{|c|}{$\begin{array}{c}\text { Non-suppression Group } \\
\text { (46 Patients) }\end{array}$} \\
\hline & & $\begin{array}{c}\text { Control } \\
\text { Group } \\
\text { (10) }\end{array}$ & $\begin{array}{l}\text { Lignocaine } \\
\text { Group } \\
\text { (26) }\end{array}$ & $\begin{array}{c}\text { Control } \\
\text { Group } \\
\text { (33) }\end{array}$ & $\begin{array}{c}\text { Lignocaine } \\
\text { Group } \\
\text { (13) }\end{array}$ \\
\hline $\begin{array}{l}\text { Ventricular } \\
\text { tachycardia } \\
\text { Ventricular } \\
\text { fibrillation }\end{array}$ & $\begin{array}{l}\text { Early } \\
\text { Late } \\
\text { Early } \\
\text { Late }\end{array}$ & = & $\underline{z}$ & $\begin{array}{l}\frac{4}{2} \\
\frac{4}{4}\end{array}$ & $\frac{2}{1}$ \\
\hline
\end{tabular}

Early $=$ Within 48 hours of infarction. Late $=$ More than 5 days after infarction. Early $=$ Within 48 hours of infarction. Late $=$
*Subsequently developed ventricular fibrillation.

Ventricular Fibrillation.-Primary ventricular fibrillation occurred in only one patient during the trial period (Table V). His ventricular ectopic activity was of the R-on-T type with a $\mathrm{QR}^{\prime} / \mathrm{QT}$ ratio of 0.55 and was not suppressed by either lignocaine bolus. Six patients developed late ventricular fibrillation after the trial period 7 to 13 days after infarction. The arrhythmia was primary in two and secondary in four. Two of these had recurrent ventricular tachycardia before the onset of fibrillation and two subsequently showed recurrent ectopics (QR'/QT ratio 0.9 and 0.89 respectively) after successful resuscitation had restored sinus rhythm. One patient had shown early ventricular tachycardia during the trial period; his initial ventricular ectopics had a $Q R^{\prime} / Q T$ ratio of 0.94 . The ventricular ectopic activity at the beginning of the trial in the seven patients who subsequently developed ventricular fibrillation was of the unifocal type in one, consecutive and multifocal in two, multifocal in three, and R-on-T in one. The last had a $Q R^{\prime} / Q T$ 
ratio of 0.55 and was the one who developed fibrillation during the trial period. However, three of the patients in the multifocal group had shown a ratio of between 0.85 and 1.0 -that is, the ectopic fell just on or before the end of the $T$ wave.

"Open" Lignocaine Therapy for Major Ventricular Arrhythmias after the Trial Period.-Five patients who developed either ventricular fibrillation or ventricular tachycardia after the trial period received "open" lignocaine in an attempt to control myocardial irritability. The dosage used is shown in Table VI. Recurrent episodes of ventricular tachycardia or fibrillation subsequently occurred in four patients who ultimately died.

TABLE VI-“'Open” Lignocaine Therapy for Ventricular Arrhythmias after Trial Period

\begin{tabular}{|c|c|c|c|c|c|}
\hline $\begin{array}{l}\text { Case } \\
\text { No. }\end{array}$ & Arrhythmia & $\begin{array}{l}\text { Interval } \\
\text { after } \\
\text { Infarction }\end{array}$ & Dose of Lignocaine & Response & Outcome \\
\hline$I$ & $\begin{array}{l}\text { Ventricular } \\
\text { fibrillation }\end{array}$ & 12 days & $\begin{array}{l}100-\mathrm{mg} \text { bolus and } \\
2 \mathrm{mg} / \mathrm{min} \text { infusion } \\
\text { for } 68 \text { hours }\end{array}$ & $\begin{array}{l}\text { No } \\
\text { suppression }\end{array}$ & Died \\
\hline II & $\begin{array}{l}\text { Ventricular } \\
\text { tachycardia }\end{array}$ & 5 days & 2 boluses of $100 \mathrm{mg}$ & $\begin{array}{l}\text { No } \\
\text { suppression }\end{array}$ & Died \\
\hline III & $\begin{array}{l}\text { Ventricular } \\
\text { fibrillation }\end{array}$ & 15 days & $100-\mathrm{mg}$ bolus and & $\begin{array}{l}\text { No } \\
\text { suppression }\end{array}$ & Died \\
\hline IV & $\begin{array}{l}\text { Ventricular } \\
\text { fibrillation }\end{array}$ & 15 days & $50-\mathrm{mg}$ bolus and & Suppression & Survived \\
\hline v & $\begin{array}{l}\text { Ventricular } \\
\text { tachycardia }\end{array}$ & 7 days & $\begin{array}{l}100-\mathrm{mg} \text { bolus and } \\
2 \mathrm{mg} / \mathrm{min} \text { infusion } \\
\text { for } 2 \text { hours }\end{array}$ & $\begin{array}{l}\text { No } \\
\text { suppression }\end{array}$ & Died \\
\hline
\end{tabular}

Mortality.-Seven patients $(18 \%)$ in the lignocaine group and $4(9.5 \%)$ in the control group died in hospital. The difference is not statistically significant $(P \simeq 0 \cdot 3)$. Details of these patients are given in Table VII.

\section{Discussion}

The present study was planned on a double-blind basis to include a selected group of patients with acute myocardial infarction who developed ventricular ectopic activity, but whose course had otherwise been uncomplicated. The dosage of lignocaine, both boluses and infusion, was similar to that given by other workers (Gianelly et al., 1967; Lown et al., 1967; Jewitt et al., 1968) and had previously proved both safe and effective in suppressing about $80 \%$ of ventricular ectopics (Chopra et al., 1969). From this earlier experience it was assumed that if suppression of ectopic activity was not evident after the two bolus injections (totalling $150 \mathrm{mg}$ of lignocaine) no better effect would result from a continuous infusion of up to $2 \mathrm{mg} /$ minute. For this reason the 24-hour infusion was administered only if ectopic activity disappeared within five minutes of either bolus.

The apparent suppression of ectopics in the control group (in $32 \%$ of patients by boluses and $72 \%$ by infusions) shows how the natural transience of these arrhythmias may lead to erroneous conclusions about the value of therapy. The present study again showed that lignocaine will suppress most ventricular ectopics, though possibly (unproved statistically) it may be less effective in multifocal or R-on-T ectopics (Table III). It may be no coincidence that all seven patients in the trial who developed ventricular fibrillation had at some time manifested ventricular ectopic beats with a $Q R^{\prime} / Q T$ ratio of less than one.

On the other hand, no evidence has been provided to show that this schedule of lignocaine therapy prevented more serious ventricular arrhythmias or influenced the hospital survival rate. The three early deaths (Table VII) occurred in patients with high Peel indices and were not immediately attributable to ventricular arrhyhmias (one asystole, two left ventricular failure with pulmonary oedema). All eight patients who died after the trial ( 7 to 42 days after infarction) had suffered large infarcts, as indicated by high serum enzymes (Table VII).

In the one situation where a really effective antiarrhythmic agent is urgently required-namely, in patients with recurrent ventricular fibrillation - we have found lignocaine as disappointing as every other drug. With increasing experience in a monitoring unit it becomes more difficult to escape the conclusion that the time and attention of the nursing and medical staff is better employed in the careful observation of arrhythmias and the prompt use of the defibrillator than in supervising routine prophylactic lignocaine administration.

We should like to thank the Pharmaceutical Manufacturing Co. Ltd. for supplying the lignocaine and saline ampoules used in this trial and also for preparing the randomized code.

\section{References}

Bennett, M. A., Wilner, J. M., and Pentecost, B. L. (1970). Lancet, 2, 909. Chopra, M. P.', Portal, R. W., and Aber, C. P. (1969). British Medical

Fournal, 1, 213 .
Gianelly, R., Von der Groeben, I. O., Spivack, A. P., and Harrison, D. C. (1967). New England fournal of Medicine, 277, 1215.

Jewitt, D. E., Kishon, Y., and Thomas, M. (1968). Lancet, 1, 266.

Lown, B., Fakhro, A. M., Hood, W. B., and Thorn, G. W. (1967). fournal of American Medical Association, $199,188$.

Mogensen, L. (1970). Acta Medica Scandinavica, Suppl. No. 513.

Nachlas, M. M., Friedman, M. M., and Cohen, S. P. (1964). Surgery, 55, 700 .

Peel, A. A. F., Semple, T., Wang, I., Lancaster, W. M., and Dall, J. L. G. (1962). British Heart fournal, 24, 745.

Pitt, A., Lipp, H., and Anderson, S. T. (1971). Lancet, 1, 612.

Rosalki, S. B. (1963). British Heart fournal, 25, 795.

Spracklen, F. H. N., Kimerling, J. J., Besterman, E. M. M., and Litchfield, J. W. (1968). British Medical fournal, 1, 89.

TABLE VII-Analysis of 11 Deaths

\begin{tabular}{|c|c|c|c|c|c|c|c|c|c|c|}
\hline \multirow{2}{*}{$\begin{array}{l}\text { Case } \\
\text { No. }\end{array}$} & \multirow{2}{*}{\multicolumn{2}{|c|}{$\begin{array}{l}\text { Age } \\
\text { and } \\
\text { Sex }\end{array}$}} & \multirow{2}{*}{$\begin{array}{c}\text { Peel } \\
\text { Index }\end{array}$} & \multicolumn{2}{|c|}{$\begin{array}{l}\text { Maximal Enzyme } \\
\text { Levels }\end{array}$} & \multirow{2}{*}{$\begin{array}{l}\text { Interval between Infarction } \\
\text { and Development of } \\
\text { Ventricular Ectopic Activity }\end{array}$} & \multirow{2}{*}{$\begin{array}{l}\text { Type of } \\
\text { Ventricular } \\
\text { Ectopics }\end{array}$} & \multirow{2}{*}{$\begin{array}{l}\text { Suppression of } \\
\text { Ventricular } \\
\text { Ectopic Activity }\end{array}$} & \multirow{2}{*}{$\begin{array}{c}\text { Nature of } \\
\text { Terminal Event }\end{array}$} & \multirow{2}{*}{$\begin{array}{l}\text { Interval between } \\
\text { Onset of } \\
\text { Therapy and Death }\end{array}$} \\
\hline & & & & SGOT & SHBD & & & & & \\
\hline \multicolumn{11}{|c|}{ Control Group } \\
\hline 1 & 45 & M. & 16 & - & - & 7 hours & $\begin{array}{l}\text { Unifocal and } \\
\text { consecutive }\end{array}$ & No & $\begin{array}{l}\text { Complete heart } \\
\text { block. Asystole }\end{array}$ & 10 hours \\
\hline 2 & & M. & 10 & 410 & 3,420 & 3 hours & Multifocal & No & $\begin{array}{l}\text { Ventricular } \\
\text {. }\end{array}$ & 23 days \\
\hline 3 & & M. & 17 & 440 & 3,170 & 2 hours & Unifocal $21 / \mathrm{min}$ & No & & 8 days \\
\hline 4 & 45 & M. & 4 & 360 & 3,630 & 4 hours & $\begin{array}{l}\text { Consecutive and } \\
\text { multifocal }\end{array}$ & No & $\begin{array}{l}\text { fibrillation } \\
\text { Ventricular } \\
\text { asystole }\end{array}$ & 42 days \\
\hline \multicolumn{11}{|c|}{ Lignocaine Group } \\
\hline 5 & 72 & F. & 13 & 113 & 630 & 8 hours & Unifocal $19 / \mathrm{min}$ & Yes & Cerebrovascular & 32 days \\
\hline $\begin{array}{l}6 \\
7\end{array}$ & & $\stackrel{\mathrm{F}}{\mathrm{M}}$. & $\begin{array}{r}15 \\
6\end{array}$ & $\overline{154}$ & $\overline{1,020}$ & $\begin{array}{l}4 \text { hours } \\
17 \text { hours }\end{array}$ & $\begin{array}{l}\text { Unifocal } 12 / \mathrm{min} \\
\text { Multifocal }\end{array}$ & $\begin{array}{l}\text { Yes } \\
\text { No }\end{array}$ & $\begin{array}{l}\text { accident } \\
\text { Pulmonary oedema } \\
\text { Recurrent } \\
\text { ventricular }\end{array}$ & $\begin{array}{l}15 \text { hours } \\
17 \text { days }\end{array}$ \\
\hline $\begin{array}{l}8 \\
9\end{array}$ & & $\begin{array}{l}\text { M. } \\
\text { F. }\end{array}$ & $\begin{array}{r}15 \\
9\end{array}$ & $\overline{320}$ & $\overline{2,830}$ & $\begin{array}{l}9 \text { hours } \\
2 \text { hours }\end{array}$ & $\begin{array}{l}\text { Unifocal } 17 / \mathrm{min} \\
\text { R-on-T }\end{array}$ & $\begin{array}{l}\text { Yes } \\
\text { No }\end{array}$ & $\begin{array}{l}\text { Pulmonary oedema } \\
\text { Cerebrovascular }\end{array}$ & $\begin{array}{l}3 \text { hours } \\
7 \text { days }\end{array}$ \\
\hline 10 & & F. & $\begin{array}{r}6 \\
14\end{array}$ & $\begin{array}{l}455 \\
410\end{array}$ & $\begin{array}{l}3,270 \\
2,750\end{array}$ & $\begin{array}{l}70 \text { hours } \\
8 \text { hours }\end{array}$ & $\begin{array}{l}\text { Unifocal } 26 / \mathrm{min} \\
\text { Unifocal and } \\
\text { consecutive }\end{array}$ & $\begin{array}{l}\text { No } \\
\text { No }\end{array}$ & $\begin{array}{l}\text { Pulmonary oedema } \\
\text { Congestive } \\
\text { cardiac failure }\end{array}$ & $\begin{array}{l}10 \text { days } \\
18 \text { days }\end{array}$ \\
\hline
\end{tabular}

SGOT $=$ Serum aspartate aminotransferase in R.F. units $1 \mathrm{ml} . \mathrm{SHBD}=$ Serum hydroxybutyrate dehydrogenase in Wroblewski units $/ \mathrm{ml}$. 